\title{
Ingestive behavior of Nellore cows and their straightbred or crossbred calves $^{1}$
}

\section{Fernando Miranda de Vargas Junior ${ }^{2}$, Francisco Stefano Wechsler ${ }^{3}$, Patrícia Rossi ${ }^{4}$, Marcus Vinicius Morais de Oliveira $^{5}$, Patrick Schmidt ${ }^{6}$}

\footnotetext{
${ }^{1}$ Pesquisa financiada pela FAPESP/CAPES.

2 Universidade Federal da Grande Dourados/Faculdade de Ciências Agrárias. Rodovia Dourados - Itahum, km 12. Caixa Postal 533, CEP: 79804-970, Dourados, MS.

3 Universidade Estadual Paulista/Faculdade de Medicina Veterinária. e Zootecnia - Departamento de Produção Animal, Botucatu, SP.

${ }^{4}$ University of Kentucky/Department Animal and Food Sciences/Lexington, $K Y$.

5 Universidade Estadual de Mato Grosso do Sul/Curso de Zootecnia, Aquidauana, MS.

6 Universidade Federal do Paraná/Departamento de Zootecnia, Curitiba, PR.
}

\begin{abstract}
This trial aimed to investigate the influence of calf genetic group on the ingestive behavior of Nellore dams and their offspring on pasture. Twenty one primiparous and multiparous Nellore cows were assigned to the experiment; 13 cows nursed straightbred Nellore calves; and eight cows nursed halfbred Simmental $\times$ Nellore calves. The observations started in the morning, as soon as identification of the animals in daylight was possible, and they lasted until after sunset, when identification became impossible. The observations were made at 3, 6, 12, 24 and 30 weeks after calving. The following events were continuosly observed: grazing, rumination, idleness, water and mineral intake, and suckling frequency and length.. The dams of straightbreds showed a shorter rumination time and longer idleness. Nellore calves showed shorter grazing time and higher suckling frequency. The ingestive behavior of Nellore cows on pasture is affected by the genetic group of their offspring, possibly because of the suckling frequency of the calves.
\end{abstract}

Key Words: crossbreeding, grazing, idleness, rumination, suckling

\section{Comportamento em pastejo de vacas Nelores amamentando bezerros Nelores ou mestiços Simental $\times$ Nelore}

RESUMO - O objetivo neste trabalho foi estudar a influência do grupo genético do bezerro nas características comportamentais de vacas nelores e de seus bezerros em pastejo. Foram usadas 21 vacas nelores (primíparas e pluríparas): 13 com bezerros nelores; e 8 com bezerros mestiços Simental $\times$ Nelore. As observações do comportamento nas pastagens começaram pela manhã, no momento em que a luminosidade permitia a identificação dos animais, e terminaram ao final da tarde, quando não era mais possível a identificação, e foram realizadas nas semanas 3, 6, 12, 24 e 30 após o parto. Foram avaliados continuamente os seguintes eventos nas vacas e nos bezerros: pastejo, ruminação, ócio, consumo de água e de mistura mineral; e frequência e duração das mamadas. As vacas com bezerros nelores apresentaram menor tempo de ruminação e maior tempo de ócio e seus bezerros, menor tempo de pastejo e maior número de mamadas. O comportamento ingestivo de vacas nelores em pastejo é influenciado pelo grupo genético do bezerro, possivelmente em decorrência da frequência das mamadas.

Palavras-chave: amamentação, cruzamento, ócio, pastejo, ruminação

\section{Introduction}

Understanding the behavior of cows and their calves on pasture may help to identify management practices that promote their well-being and it results in improving the overall efficiency of a cow-calf system (Alencar et al., 1995; 1996).

Crossbreeding in Brazilian beef cattle production has become more popular, mainly through the use of crosses between Zebu and European breeds, because of the benefits brought by heterosis and complementarity (Kippert et al., 2008). In crossbreeding systems, it is usual to evaluate the performance of crossbred calves (Koger, 1980; Long, 1980), but little attention has been given to the behavior of cows nursing calves on pasture. This dearth of information is particularly important in the case of Nellore dams, which constitute the majority of beef cows in Brazil.

Total suckling time and daily suckling frequency decrease as calf age increases (Reinhard \& Reinhardt, 1981) and may also be influenced by the dam's milk yield

Received August 11, 2008 and acepted May 7, 2009

Corresponding author:fernandojunior@ufgd.edu.br 
(Odde et al., 1985). Variations in suckling behavior depend on a dam's ability to satisfy her calf's nutritional needs (Day et al., 1987), as well as on the pasture quality and stocking rate to which the dam-calf pair is submitted (Espasandin et al., 2001).

One of the few articles on behavior of Nellore cows on pasture was published by Alencar et al. (1996), who compared the behavior of Nellore to that of Canchim cows. The authors observed greater daytime grazing in Canchim cows and a positive, albeit small correlation $(r=0,27)$ between milk yield and grazing time in Nellore cows.

In the cow-calf relationship a particularly important behavior is nursing, which exerts a strong regulatory function on postpartum ovarian activity. An increase in the length of postpartum anestrus is associated to the level in which a dam is stimulated by her calf (Wettemann et al., 1978; Randel, 1981; Williams, 2001). Thus, the understanding of their behavior is important to establish conclusions about postpartum reproductive functions (Day et al., 1987).

We have not found any literature on the behavior of Nellore cows and on their straightbred or crossbred offspring raised on pasture. Therefore, the present study was conducted with the objective to study the influence of calf genetic group on the ingestive behavior of Nellore dams and their offspring on pasture.

\section{Material and Methods}

The experiment was conducted at the Fazenda Experimental São Manuel, which belongs to Universidade Estadual Paulista (UNESP), Faculdade de Medicina Veterinária e Zootecnia, located in São Manuel municipality, São Paulo state.

Out of a group of 53 Nellore females, half were randomly chosen for insemination with semen from a Nellore sire and the other half were inseminated with semen from a Simmental sire. Both bulls had an expected progeny difference around zero. Thirty seven females calved, of which 24 produced straightbreds and 13 produced crossbreds. The calvings occurred from December 1, 2001 to February 4, 2002. Twentyone primiparous and multiparous cows were randomly chosen out of these 37 cows: 13 nursed Nellore calves (four males and nine females) and eight nursed halfbred Simmental $\times$ Nellore calves (six males and two females). The cows were distributed in three blocks, according to parturition date, with an average interval of 20 days from one block to another: A - five cows (two straightbred and three crossbred calves); $\mathrm{B}$ - nine cows (seven straightbred and two crossbred calves); and block C - seven cows (four straightbred and three crossbred calves). This subdivision was necessary so to obtain more homogeneous lots and fewer animals per lot, which would make observations easier.

The total area of the farm is approximately 250 hectares, divided into 14 paddocks, in which an average stocking rate of $0.9 \mathrm{AU} / \mathrm{ha}$ was kept during the experiment. All animals in the experiment were kept together in a common paddock, except during the observation periods when one block at a time was transferred to the observation paddock, as follows. At least three days prior to the observations, all cows and calves which belonged to a block that was going to be observed were moved to a 11.7 ha paddock, in which the topography made it possible to the observers to see the whole area. This paddock was composed almost entirely by Brachiaria decumbens, with a few spots of Brachiaria brizantha, and it was kept, during the observation periods, under an average stocking rate of 0.7 AU/ha. All animals received mineral mix ad lib. The sanitary and management procedures followed the routine adopted in the Experimental Farm.

Ingestive behavior was observed following the methodology described by Alencar et al. (1995), with a few modifications. The observations started at sunrise, as soon as there was enough daylight to make the animals clearly visible and ended in late afternoon, when they were no more clearly visible. For better identification, all animals were marked with hair dye on their back, rump and front. As a stationary observation base, we used a tractor connected to a cart, an equipment that was familiar to the animals. The tractor hood served as an observation tower. The observations were made by using binoculars or, when it was possible, without them.

Each block was observed on weeks 3, 6, 12, 24 and 30 postpartum. The observations were made directly and continuously, including the beginning and ending of each of the following events: grazing, rumination, nursing, water consumption, mineral salt intake and idleness (absence of the preceding activities). Thus, it was possible to calculate, for each animal in an observation period, the total time spent on grazing, rumination and idleness, as well as the nursing frequency, the average time spent on each nursing and the total nursing time during each observation. Nursing was considered to have started when suction effectively occurred, and aborted trials were unconsidered; the end of nursing was set when the calf ceased to seek its dam's udder. A new nursing period was set when this process recommenced. No more than two cow-calf pairs were alloted to each observer, and each observer received a marking paper sheet for every animal alloted to him/her, with columns on it for continuous notes of all occurrences. 
In every observation week, the amount of available forage ( $\mathrm{kg} \mathrm{DM} / \mathrm{ha}$ ) in the observation paddock was estimated by means of a $625 \mathrm{~cm}^{2}$ square that was haphazardly thrown throughout the paddock. The forage contained within the square was cut at approximately $5 \mathrm{~cm}$ away from the soil, and the process was performed 10 times to obtain a composite sample, which was taken to the laboratory, weighed fresh and dried in a forced-draft oven at $60^{\circ} \mathrm{C}$ for estimating its dry matter content.

Rainfall, average wind speed and average low and high temperatures were recorded at the meteorological station of Faculdade de Ciências Agronômicas of UNESP, which is located on the same farm.

The experiment was conducted in a randomized block design with more than one replicate per block and repeated measures. The results were statistically analyzed by means of restricted maximum likelihood, through the MIXED procedure (Littell et al., 1996) of SAS (version 6.12). The statistical model considered the following fixed effects as applied to the experimental units (animals): block, calf genetic group, calf gender, the linear effects of total observation time and available dry matter (covariates), as well as the linear and quadratic effects of parity. The following fixed effects were considered as applied to the repeated measures: linear and quadratic effects of days postpartum, the interactions between these and calf genetic group and gender, as well as the following covariables: milk yield, rainfall, wind speed and average, low and high temperatures. The model included, as random effects, cows or calves within each combination of block, gender and genetic group (error a); and residuals (error b).

\section{Results and Discussion}

The effects of parity, milk yield, rainfall, wind speed and temperature were removed from the final model since they were not significant $(\mathrm{P}>0.10)$.

The average observation time was 12.3 hours (740.5 minutes), ranging from 11.3 hours in the winter to 13.7 hours in the summer. Although no difference was detected between genetic groups for the grazing time of the cows (Table 1), an interaction ( $\mathrm{P}=0.0001)$ was detected for this variable between genetic group and days postpartum. The grazing time increased with days postpartum and gradually stabilized; this increase was faster in the cows nursing Nellore calves (Figure 1). From a practical point of view, differences between genetic groups were small. The gregarious behavior of cattle may have hindered the

Table 1 - Least-squares means for grazing, rumination and idleness of Nellore dams of straightbred or crossbred calves

\begin{tabular}{|c|c|c|c|c|c|}
\hline Variable & Calf genetic & group & Mean(minutes/day) & Standard error (minutes/day) & $\mathrm{P}$ \\
\hline \multirow[t]{2}{*}{ Grazing } & Nellore & & 462 & 6.02 & 0.505 \\
\hline & $1 / 2$ Simmental $1 / 2$ & Nellore & 467 & 7.35 & \\
\hline \multirow[t]{2}{*}{ Rumination } & Nellore & & 148 & 3.73 & 0.030 \\
\hline & $1 / 2$ Simmental $1 / 2$ & Nellore & 162 & 4.70 & \\
\hline \multirow[t]{2}{*}{ Idleness } & Nellore & & 124 & 5.52 & 0.022 \\
\hline & $1 / 2$ Simmental $1 / 2$ & Nellore & 108 & 6.72 & \\
\hline
\end{tabular}

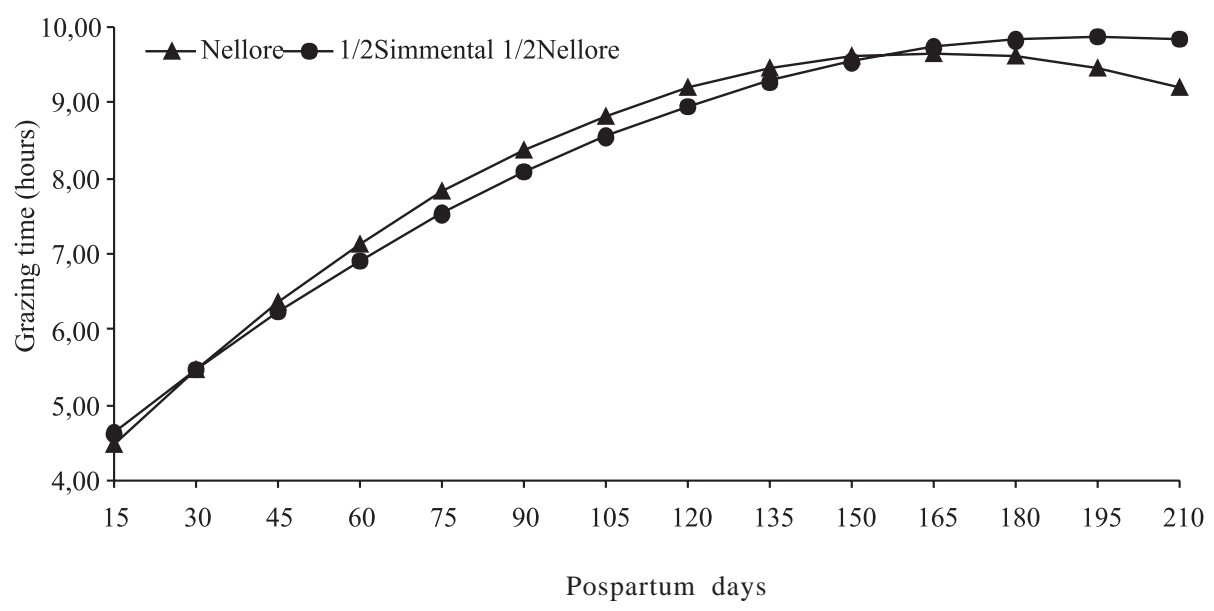

Figure 1 - Grazing time of Nellore dams of straigtbred or crossbred calves, as adjusted to postpartum days. Nellore $=20463+4.5663 X-0.013877 X^{2} ; 1 / 2$ Simmental $1 / 2$ Nellore $=224.73+3.7579 X-0.0095849 X^{2}$. 
expression of genetic group differences. Possibly more detailed observations on the type of grazing, such as bite rate and size, could better explain the effects observed.

Alencar et al. (1996) have emphasized that grazing time may be associated with forage availability and calf age, because, as calves grow up, their milk intake is reduced and their grazing ability increases, which allows their dams to graze less. However, when forage availability decreases, grazing time and number of bites increase, but bite size and hourly intake decrease, which increases the total grazing time, as a mechanism for increasing total daily intake (Rovira, 1996). In the present experiment, the adjusted grazing time increased with days postpartum (Figure 1), which is more closely linked to a reduction in quality than to a reduction in availability since availability was included as a covariable $(\mathrm{P}<0,05)$ in the model. On the average, the forage availability was $1,871 \mathrm{~kg} \mathrm{DM} / \mathrm{ha}$ (ranging from 1,165 to $2,313 \mathrm{~kg} \mathrm{DM} / \mathrm{ha}$ ).

Normal values for grazing times during 24 hours, according to Rovira (1996), range from 7 to 10 hours; 70\% of this grazing occurs during daytime and the remaining $30 \%$ during the night. Using this proportion and considering that the average observed grazing time was 7.7 hours (464.5 minutes), one may admit that the average grazing time during 24 hours was 11.06 hours. Therefore, the estimated grazing time was high, above the upper "normal" limit. Nevertheless, values close to those found in the present experiment were reported by Polli \& Lobato (1984) and Alencar et al.(1996), who observed grazing times above 7 hours during daytime.

The dams of Nellore calves showed a lower rumination time (Table 1); there was also an interaction $(\mathrm{P}=0.0019)$ between genetic group and days postpartum. Rumination time decreased as days postpartum increased for both dam groups; however, the dams of Nellore calves showed a shorter rumination time at the beginning, which decreased less steeply, such that the difference between dam groups decreased gradually (Figure 2). According to Welch \& Hooper (1993), the time spent on rumination depends on the amount of dry matter ingested, which is affected mainly by grazing time. The decrease in rumination time as days postpartum increased was probably due to a lower dry matter intake caused by a gradual lowering in forage quality and availability, which the increased grazing time could not compensate for. This was confirmed by Roberts (2009).

The dams of Nellore calves showed longer idleness (Table 1). An interaction ( $\mathrm{P}=0.0058)$ between dam group and days postpartum was also observed for this variable. The difference between dam groups decreased as days postpartum increased (Figure 3 ). As expected, when grazing time increased, idleness decreased. The increase in grazing time and the decrease in rumination and idleness were steeper during the first weeks postpartum. The longer idleness during the first weeks and its reduction with days postpartum may be partially attributed to the longer time dedicated to the calves during the initial phase. From the $12^{\text {th }}$ week onwards, milk consumption ceases to be an important part of a calve's dry matter intake (Rovira, 1996), and it seeks its dam less often.

Suckling frequency was higher in the Nellore calves (Table 2), and diminished as the calves grew older (Figure 4). No difference was observed between genetic groups for total time spent suckling or for suckling length (Table 2). Das et al. (2000) observed a longer suckling time, length and frequency in Zebu calves than in crossbreds. Odde et al. (1985) asserted that higher milk yield and calf weight

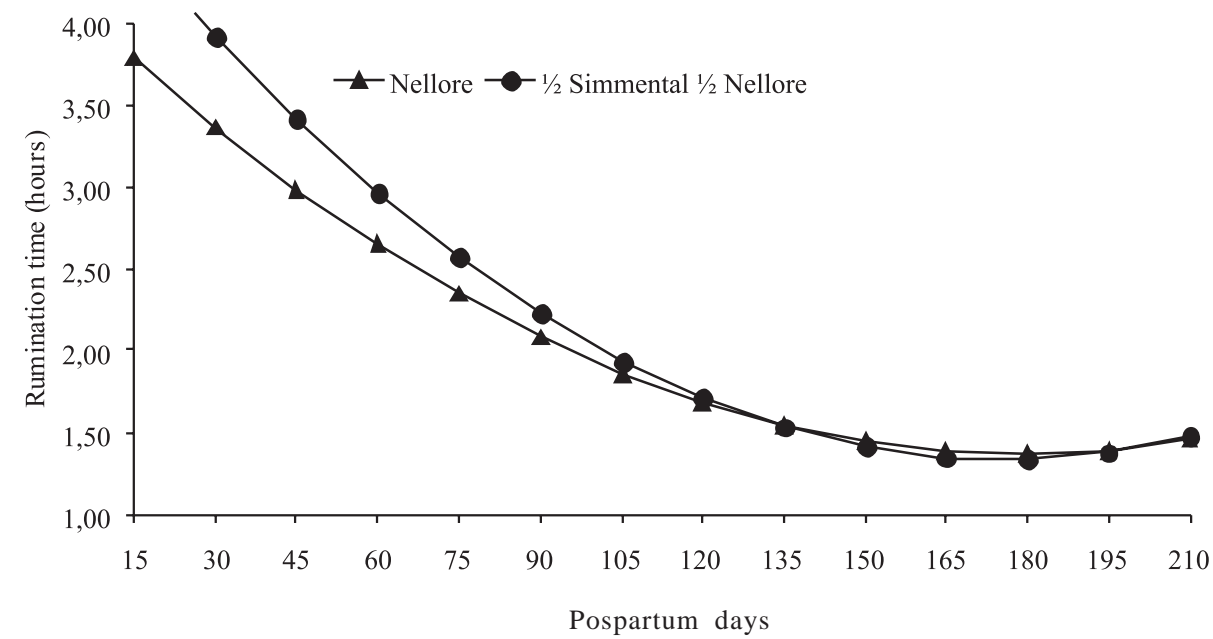

Figure 2 - Rumination time of straightbred or crossbred calves, as adjusted for postpartum days. Nellore $=255.22-1.9324 \mathrm{X}+0.005395 \mathrm{X}^{2} ; 1 / 2$ Simmental $1 / 2$ Nellore $=306.56-2.5861 \mathrm{X}+0.007382 \mathrm{X}^{2}$. 


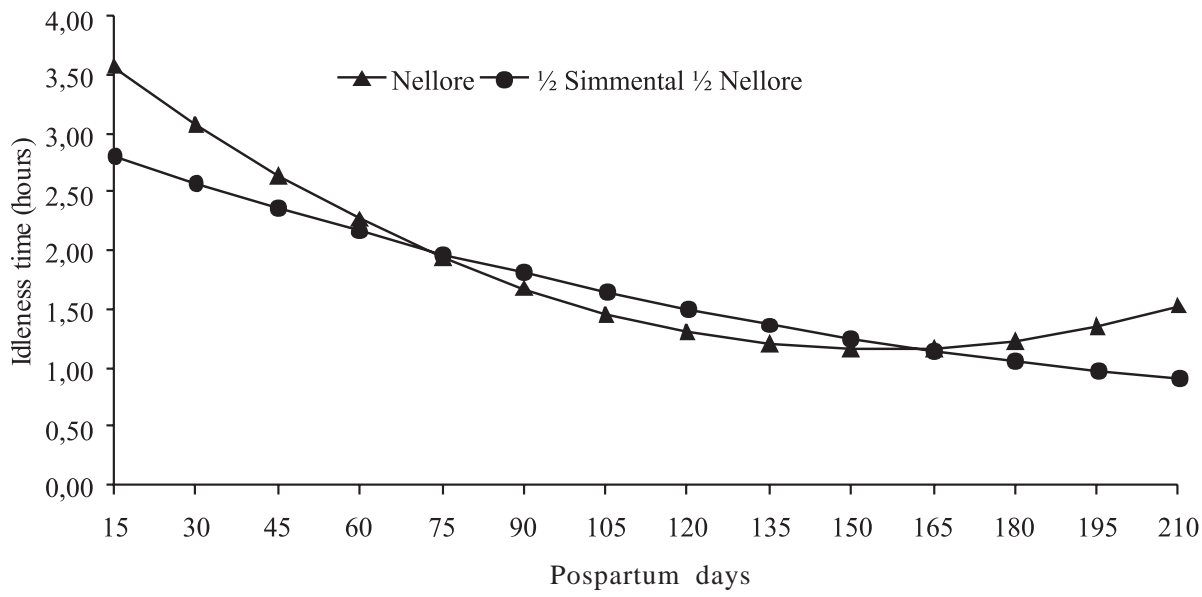

Figure 3 - Idleness of Nellore dams of straightbred or crossbred calves, as adjusted to postpartum days. Nellore $=246.99-2.2983 X+0.00741851 X^{2} ; 1 / 2$ Simmental $1 \frac{1}{2}$ Nellore $=182.29-0.9830 X+0.00178092 X^{2}$.

Table 2 - Adjusted means of straightbred or crossbred calves for frequency, total daily length and individual length of suckling and for grazing, rumination and idleness times

\begin{tabular}{|c|c|c|c|c|}
\hline Variable & Calf's genetic group or sex & Adjusted mean & Standard error & $\mathrm{P}$ \\
\hline \multirow[t]{2}{*}{ Suckling frequency (times/day) } & Nellore & 3.68 & 0.17 & 0.034 \\
\hline & $1 / 2$ Simmental $1 / 2$ Nellore & 3.02 & 0.21 & \\
\hline \multirow[t]{2}{*}{ Total suckling time (minutes/day) } & Nellore & 26.6 & 1.24 & 0.394 \\
\hline & $1 / 2$ Simmental $1 / 2$ Nellore & 24.8 & 1.50 & \\
\hline \multirow[t]{2}{*}{ Time spent on each suckling (minutes) } & Nellore & 7.42 & 0.28 & 0.299 \\
\hline & $1 / 2$ Simmental $1 / 2$ Nellore & 7.91 & 0.34 & \\
\hline \multirow[t]{2}{*}{ Grazing (minutes/day) } & Nellore & 244.4 & 6.75 & 0.067 \\
\hline & $1 / 2$ Simmental $1 / 2$ Nellore & 263.3 & 8.30 & \\
\hline \multirow[t]{2}{*}{ Rumination (minutes/day) } & Males & 61.2 & 5.15 & 0.132 \\
\hline & Females & 49.6 & 5.48 & \\
\hline \multirow[t]{2}{*}{ Idleness (minutes/day) } & Nellore & 409.8 & 7.52 & 0.138 \\
\hline & $1 / 2$ Simmental $1 / 2$ Nellore & 388.0 & 9.16 & \\
\hline
\end{tabular}

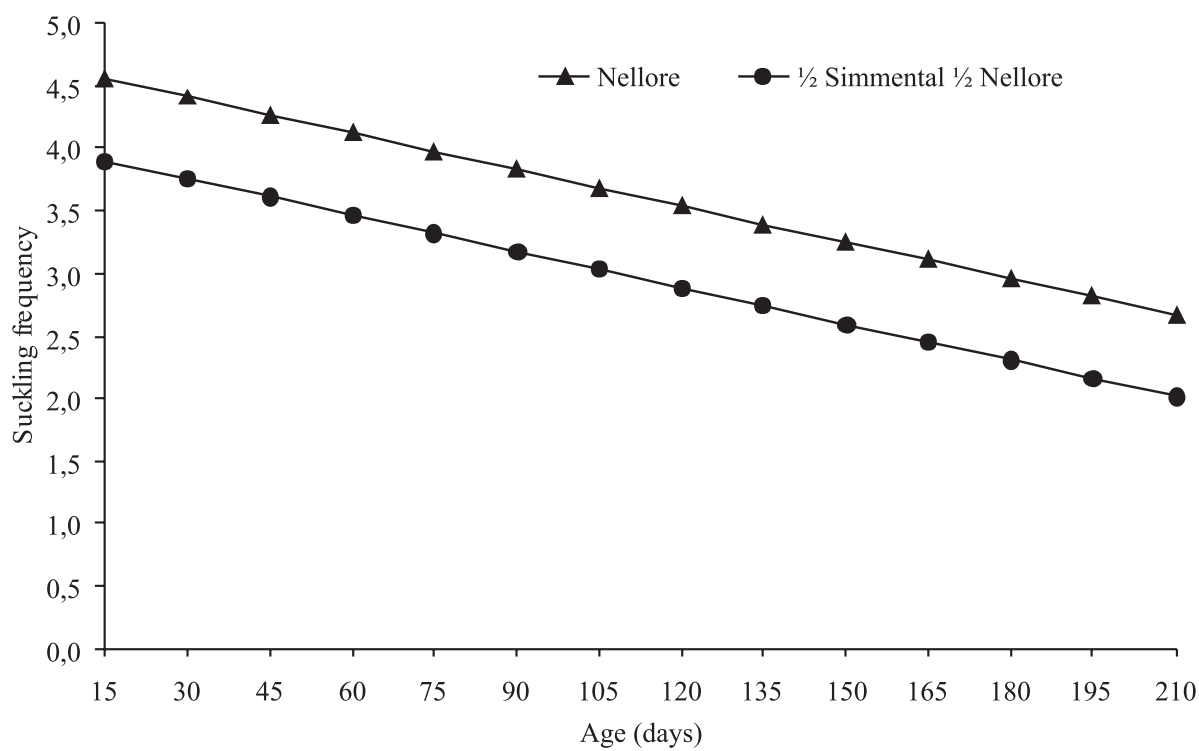

Figure 4 - Suckling frequency of straightbred or crossbred calves, as adjusted for age. Nellore $=5.48-0.01144 \mathrm{X} ; 1 / 2$ Simmental $1 / 2$ Nellore $=4.82-0.01144 \mathrm{X}$. 
gain are associated to lower suckling frequency. Vargas Jr. et al. (2003), observed higher milk consumption until weaning in halfbred Simmental $\times$ Nellore calves, chiefly during the first 63 days. For this reason, one can conclude that the halfbreds ingested a higher amount of milk in each suckling episode.

Our results are in agreement with the literature, mainly with respect to: the shortening of total suckling time as calves grow older (Das et al., 2000; Espasandin et al., 2001); no observed change in mean suckling length during the postpartum period (Day et al., 1987); decrease in suckling frequency regarded to age (Espasandin et al., 2001); and no observed gender effect on suckling variables (Reinhardt \& Reinhardt, 1981).

The crossbred calves showed a longer grazing time (Table 2). As the calves grew older, an increase in grazing time was observed, and this increase was faster $(\mathrm{P}=0.067)$ in the crossbreds (Figure 5), the difference becoming clear from the second month onwards. This difference can be attributed to the higher growth potential of the crossbreds, which creates a higher nutritional demand and forces them to obtain nutrients from pasture, since milk becomes insufficient. There may be a misunderstanding when one attributes the higher weight gain of a calf exclusively to its dam's milk yield, because a lower or insufficient yield forces it to eat more forage, in an effort to compensate for a lower intake of milk dry matter (Ansotegui et al., 1991).

No effect of genetic group or gender was observed for calf rumination time (Table 2 ), but there was some evidence of interaction ( $\mathrm{P}=0.0989$ ) between sex and age (Figure 6). We offer no explanation for this fact, but one must consider that rumination is difficult to measure, mainly when calves are still small and poorly visible, which hinders a precise observation of rumination.

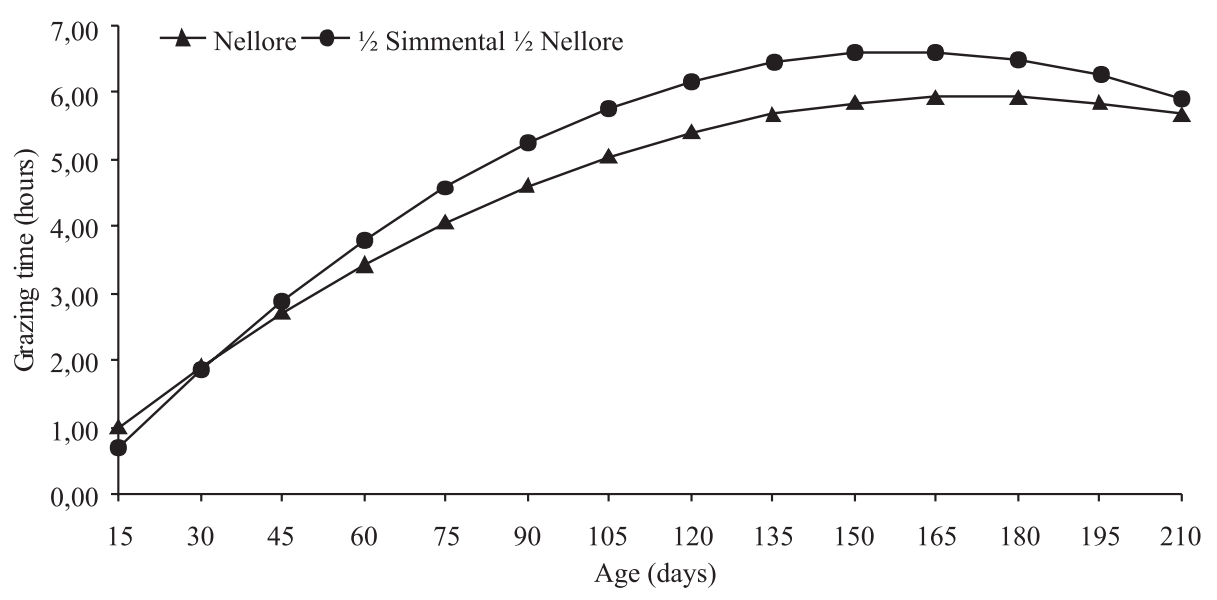

Figure 5 - Time spent on grazing by straightbred or crossbred calves, as adjusted for age. Nellore $=-0.43+4.16 X-0 ; 012 X^{2} ; 1 / 2$ Simmental $1 / 2$ Nellore $=-37.37+5.45 X-0.017 X^{2}$.

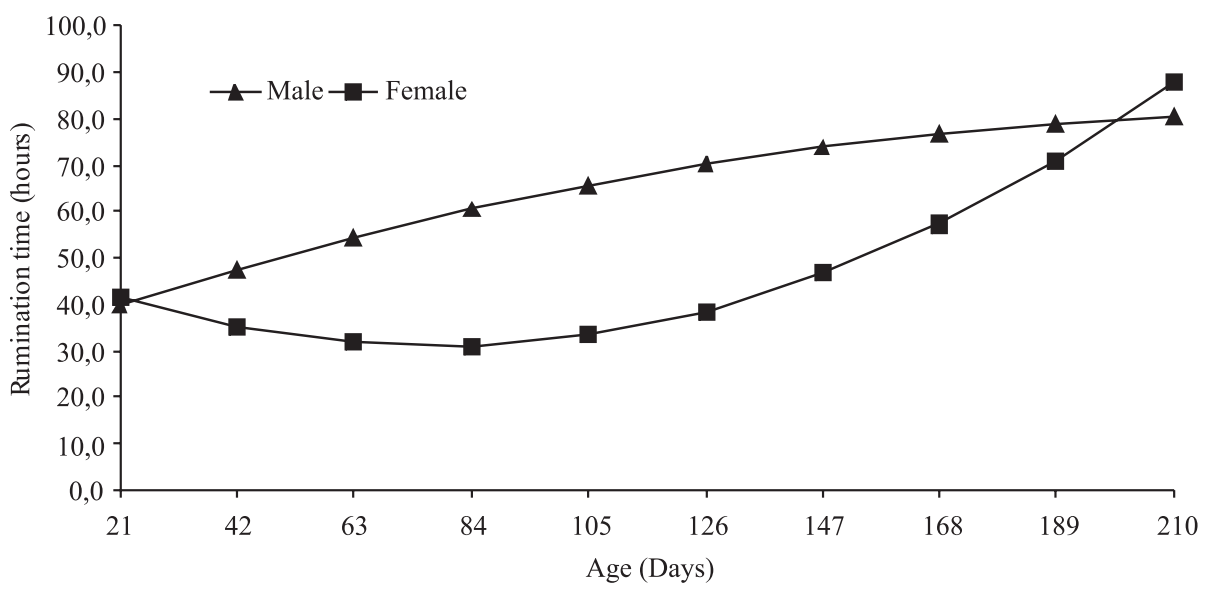

Figure 6 -Time spent on rumination by male or female calves, as adjusted for age. Males $=31.30+0.4196 \mathrm{X}-0.00089 \mathrm{X}^{2} ;$ Females $=50.78-0.5071 \mathrm{X}-0.00325 \mathrm{X}^{2}$. 
Calf idleness showed no difference between genetic groups (Table 2 ), but an interaction $(\mathrm{P}=0.0001)$ between genetic group and age was observed (Figure 7): idleness decreased with age, but faster in the crossbreds. As already discussed, the straightbreds suckled more frequently; and we also observed, albeit qualitatively, that each time a calf seeked its dam, both interchanged caresses before or after nursing, and this interaction appeared to be more intense between the straightbreds and their dams. All these factors may have contributed to the slower decrease of idleness in the Nellore calves and the longer idleness of their dams.

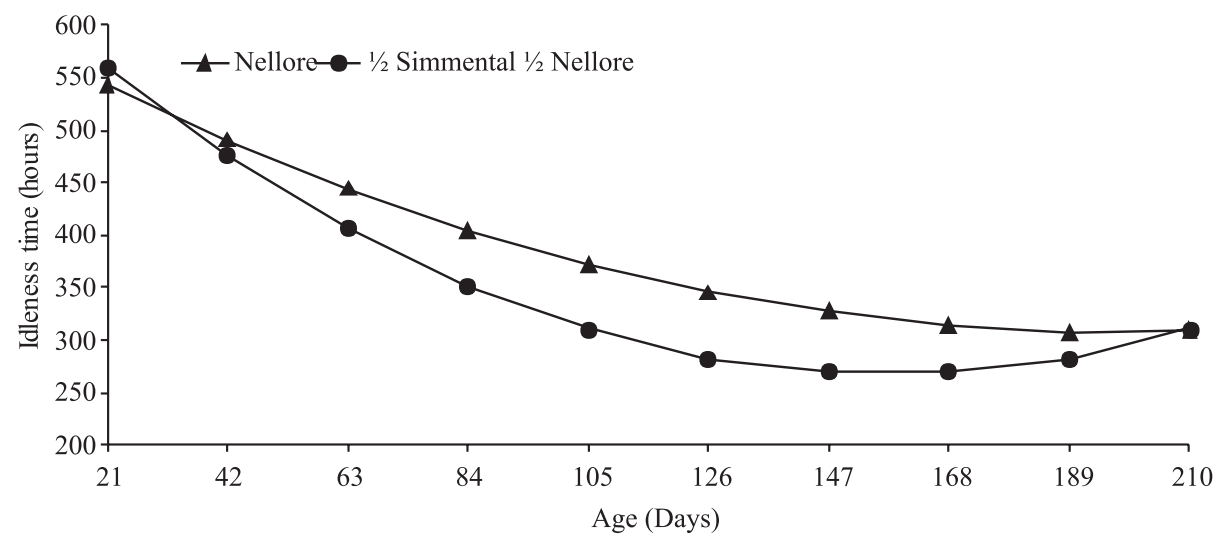

Figure 7 - Idleness of straightbred and crossbred calves, as adjusted for calf age. Nellore $=663.02-2.9956 \mathrm{X}+0.0076 \mathrm{X}^{2} ; 1 / 2$ Simmental $1 / 2$ Nellore $=685.09-4.925 \mathrm{X}+0.0156 \mathrm{X}^{2}$.

\section{Conclusions}

Nellore cows change their diurnal behavior according to the genetic group of their calves: they spend more time ruminating and less time in idleness when their calves are crossbreds. Nellore calves suckle more frequently during daytime than $1 / 2$ Simmental $1 / 2$ Nellore calves, whereas these crossbreds spend more time grazing. More attention should be given by scientists to behavioral characteristics of cattle, especially when dealing with crossbreds, given the dearth of information in literature and the possibility that these variables interfere with experimental data.

\section{References}

ALENCAR, M.M.; CRUZ, G.M.; TULLIO, R.R. et al. Características da amamentação de bezerros da raça Canchim e cruzados Canchim Nelore. Revista da Sociedade Brasileira de Zootecnia, v.24, n.5, p.706-714, 1995.

ALENCAR, M.M.; TULLIO, R.R.; CRUZ, G.M. et al. Comportamento de pastejo de vacas de corte. Revista da Sociedade Brasileira de Zootecnia, v.25, n.1, p.13-21, 1996.

ANSOTEGUI, R.P.; HAVSTAD, K.M.; WALLACE, J.D. et al. Effects of milk intake on forage intake and performance of suckling range calves. Journal of Animal Science, v.69, p.899-904, 1991.

DAS, S.M.; REDBO, I.; WIKTORSSON, H. Effect of age of calf on suckling behavior and other behavioral activities of zebu and crossbred calves during restricted suckling periods. Applied Animal Behaviour Science, v.67, p.47-57, 2000.
DAY, M.L.; IMAKAWA, K.; CLUTTER, A.C. et al. Suckling behavior of calves with dams varying in milk production. Journal of Animal Science, v.65, p.1207-1212, 1987.

ESPASANDIN, A.C.; PACKER, I.U.; ALENCAR, M.M. Produção de leite e comportamento de amamentação em cinco sistemas de produção de gado de corte. Revista Brasileira de Zootecnia, v.30, n.3, p.702-708, 2001.

KIPPERT JR., C.; RORATO, P.R.N.; LOPES, J.S. et al. Efeitos genéticos aditivos diretos e maternos e heterozigóticos sobre os desempenhos pré e pós-desmama em uma população multirracial Aberdeen Angus x Nelore. Revista Brasileira de Zootecnia, v.37, n.8, p.1383-1391, 2008

KOGER, M. Effective crossbreeding systems utilizing zebu cattle. Journal of Animal Science, v.50, p.1215-1220, 1980.

LitTELL, R.C.; MILliKEN, G.A.; STROUP, W.W. et al. SASâ System for Mixed Models, Cary: SAS Institute Inc., 1996. $633 p$.

LONG, C.R. Crossbreeding for beef production: experimental results. Journal of Animal Science, v.51, p.1197-1223, 1980.

ODDE, K.G.; KIRACOFE, G.H.; SHALLES, R.R. Suckling behavior in range beef calves. Journal of Animal Science, v.61, n.2, p.631-642,1985.

POLLI, V.A.; LOBATO, J.F.P. Comportamento de bovinos de corte. 1. Vacas de corte. In: REUNIÃO ANUAL DA SOCIEDADE BRASILEIRA DE ZOOTECNIA, 21., 1984, Belo Horizonte. Anais... Belo Horizonte: Sociedade Brasileira de Zootecnia, 1984. p.109.

RANDEL, R.D. Effect of once-daily suckling on postpartum interval and cow-calf performance of first-calf Brahman x Hereford heifers. Journal of Animal Science, v.53, p.755-757, 1981.

REINHARD, V.; REINHARDT, A. Natural suckling performance and age of weaning in zebu cattle (Bos indicus). Journal Agricultural Science, v.96, p.309, 1981.

RODRIGUES, W.B. Desempenho e comportamento de vacas nelores e suas crias puras ou mestiças no Brasil central. 
2009. 73f. Tese (Doutorado em Nutrição e Produção Animal) Universidade Estadual Paulista/Faculdade de Medicina Veterinária e Zootecnia, Botucatu.

ROVIRA, J. Manejo nutritivo de los rodeos de cria em pastoreo. Montevideo: Hemisferio Sur, 1996. 288p.

VARGAS JR, F.M.; WECHSLER, F.S.; ROSSI, P. et. al. Ganho de peso e consumo de leite de bezerros nelores e $1 / 2$ simental $1 / 2$ nelore. In: REUNIÃO ANUAL DA SOCIEDADE BRASILEIRA DE ZOOTECNIA, 40., 2003, Santa Maria. Anais... Santa Maria: Sociedade Brasileira de Zotoecnia, 2003. (CD-ROM).
WELCH, J.C.; HOOPER, A.P. Ingestion de alimentos y água. In: CHURCH, D.C. (Ed.) El rumiante fisilogía digestive y nutrición. Zaragoza: Acribia, 1993. p.117-126.

WETTEMANN, R.P.; TURMAN, E.J.; WYATT, R.D. et al. Influence of suckling intensity on reproductive performance of range cows. Journal of Animal Science, v.47, p.342-346, 1978.

WILLIAMS, G.L. Implicações de amamentação e manejo da cria na eficiência reprodutiva futura de vacas de corte. In: NOVOS ENFOQUES NA PRODUÇÃO E REPRODUÇÃO DE BOVINOS, 5., 2001. Uberlândia. Anais... Belo Horizonte: UFMG, 2001. p. 65-73. 